\title{
Alktivitas Antihiperglikemik dari Ekstrak Etanol dan Heksana Tumbuhan Suruhan (Peperomia pellucida [L.] Kunth) pada Tikus Wistar (Rattus norvegicus L.) yang Hiperglikemik
}

\author{
Sariyana Togubua*, Lidya I. Momuata, Jessy E. Paendonga, Navila Salmaa \\ aJurusan Kimia, FMIPA, Unsrat, Manado
}

K A T A K U N C

Peperomia pellucida [L]. Kunth

Tumbuhan suruhan

Kadar glukosa darah

Hiperglikemik

\begin{abstract}
A B S T R A K
Telah dilakukan penelitian kadar glukosa darah tikus wistar yang hiperglikemia pada pemberian ekstrak etanol dan heksana tumbuhan suruhan (Peperomia pellucida [L]. Kunth). Penelitian ini menggunakan metode uji toleransi glukosa, terhadap 16 ekor tikus jantan wistar yang hiperglikemia akibat diinduksi sukrosa. Selanjutnya, tikus dibagi dalam 4 kelompok perlakuan yaitu kelompok kontrol negatif (K-) diberi $\mathrm{CMC} 0,5 \%$, kelompok kontrol positif $(\mathrm{K}+)$ diberi Glibenklamid dosis $0,45 \mathrm{mg} / \mathrm{kgBB}$, kelompok ekstrak etanol tumbuhan suruhan (EETS) dosis $40 \mathrm{mg} / \mathrm{kgBB}$, dan kelompok ekstrak heksana tumbuhan suruhan (EHTS) dosis 40 $\mathrm{mg} / \mathrm{kgBB}$. Setiap kelompok terdiri dari 4 ekor tikus. Kadar glukosa darah tikus diukur dengan alat Drglukometer pada menit ke-30, 60, dan 120 setelah diberikan perlakuan. Hasil penelitian menunjukkan bahwa pada menit ke-120, kadar glukosa darah tikus pada kelompok EETS dan EHTS masing-masing turun sebesar 54,57\% dan 51,25\%, dan tidak berbeda nyata dengan $\mathrm{K}(+)$. Kadar glukosa darah kelompok $\mathrm{K}(+)$ dan EETS pada menit ke-120 mencapai kadar yang sama dengan keadaan basal (normal). Penelitian ini menyimpulkan bahwa ekstrak etanol dan heksana tumbuhan suruhan dengan dosis $40 \mathrm{mg} / \mathrm{KgBB}$ memiliki efek hipoglikemik pada tikus jantan wistar yang hiperglikemia.

\begin{tabular}{l}
\hline A B S T R A C T \\
A study on blood glucose level in hyperglycemic wistar rats treated \\
with ethanol and hexane extracts of suruhan (Peperomia pellucida [L]. \\
Kunth) had been done. This study used glucose tolerance test method \\
applied on 16 male wistar rats which were hyperglycemic by sucrose \\
induction. The rats were divided into four treatment groups, each of which \\
contained four rats, which were negative control (K-) group treated with \\
CMC 0.5\%, positive control (K+) group treated with glibenclamide 0.45 \\
mg/kg body weight, group treated with ethanol extract of $P$. pellucida \\
(EETS) 40 mg/kg body weight, and group treated with hexane extract of $P$. \\
pellucida (EHTS) 40 mg/kg body weight. Glucose level in rat blood was \\
measured using Drglucometer at minute 30,60 , and 120 after treatment. \\
The results showed that at minute 120 the blood glucose level of EETS \\
and EHTS was decreased by $54.57 \%$ and $51.25 \%$, respectively, which \\
were not significantly different from $\mathrm{K}(+)$. At minute 120 , blood glucose of \\
K(+) and EETS reached the same level with that of basal (normal) state. It \\
was concluded that ethanol and hexane extract of P. pellucida 40 mg/kg \\
body weight had hypoglycemic effect on hyperglycemic wistar rats.
\end{tabular}
\end{abstract}

AVAILABLE ONLINE

20 Oktober 2013
K E YW O R D

Suruhan plant

Blood glucose level

Hyperglycemic
*Corresponding author: Jurusan Kimia FMIPA UNSRAT, Jl. Kampus Unsrat, Manado, Indonesia 95115; Email address: sariyana.togubu@yahoo.com Published by FMIPA UNSRAT (2013) 


\section{Pendahuluan}

\subsection{Latar Belakang}

Sejak zaman dahulu masyarakat Indonesia sudah mengenal dan memanfaatkan tumbuhan sebagai obat untuk mengobati beberapa penyakit. Dewasa ini, pengetahuan tentang tumbuhan obat merupakan budaya bangsa yang diwariskan secara turun-temurun. Sebagian masyarakat lebih menyukai pengobatan dengan tumbuhan obat daripada obat paten hasil sintesis. Mereka meyakini bahwa tumbuhan obat lebih aman dikonsumsi dan kurang menimbulkan efek samping yang tidak diinginkan, sehingga memilih menggunakan obat herbal untuk menyembuhkan penyakitnya.

Penyakit diabetes melitus merupakan salah satu penyakit yang banyak diderita oleh masyarakat Indonesia. Diabetes mellitus atau yang dikenal dengan nama kencing manis adalah suatu penyakit yang ditandai oleh meningkatnya kadar gula (glukosa) darah melebihi kadar normalnya. Diabetes Mellitus disebabkan oleh tubuh kekurangan insulin, dengan gejala klinis yang umum seperti banyak makan, banyak minum, dan sering kencing (Kawatu et al., 2013).

Pengobatan diabetes mellitus adalah pengobatan menahun dan seumur hidup. Penggunaan obat sintestik untuk pengobatan diabetes mellitus dalam jangka waktu lama dapat menimbulkan efek samping yang tidak diinginkan. Oleh karena itu, salah satu upaya dalam penanganan diabetes mellitus adalah dengan menggunakan tumbuhan herbal sebagai obat alternatif.

Salah satu spesies tumbuhan yang memiliki khasiat sebagai obat antidiabetes (antihiperglikemik) yaitu tumbuhan suruhan (Peperomia pellucida (L.) Kunth). Secara empiris, tumbuhan suruhan digunakan masyarakat sebagai lalap atau diminum sebagai minuman herbal (Dalimartha, 2006).

Hasil pengujian Kusumawarni et al., (2012) menunjukkan bahwa fraksi etil asetat dari tumbuhan suruhan memiliki aktivitas antidiabetes terhadap tikus yang hiperglikemik akibat diinduksi dengan aloksan. Persentase penurunan kadar glukosa darah pada penelitian tersebut sebesar $53.44 \%$ dan tidak berbeda nyata dengan kontrol positif (obat antidiabetes). Namun sejauh ini, belum ditemukan informasi adanya penelitian mengenai perbandingan ekstrak polar dan non-polar dari tumbuhan suruhan pada penderita hiperglikemik akibat diinduksi dengan sukrosa. Berdasarkan uraian tersebut maka peneliti tertarik untuk menguji efek ekstrak polar dan non-polar tumbuhan suruhan terhadap penurunan kadar glukosa darah tikus wistar yang diinduksi sukrosa dengan menggunakan pelarut etanol (polar) dan heksana (non-polar).

\subsection{Perumusan Masalah}

Apakah ekstrak etanol dan heksana dari tumbuhan suruhan (Peperomia pellucida [L.] Kunth) mempunyai efek yang berbeda sebagai antihiperglikemik pada tikus wistar (Rattus norvegicus L.) yang hiperglikemia?

\subsection{Tujuan Penelitian}

Penelitian ini bertujuan mengukur kadar glukosa darah tikus wistar yang hiperglikemia pada pemberian ekstrak etanol dan heksana tumbuhan suruhan.

\subsection{Manfaat Penelitian}

Penelitian ini diharapkan dapat memberikan informasi mengenai pemanfaatan tumbuhan suruhan sebagai tumbuhan obat dalam menurunkan kadar glukosa darah pada penderita diabetes melitus, sehingga nantinya dapat digunakan sebagai obat alternatif diabetes mellitus yang murah serta relatif aman penggunaannya dalam mengobati penyakit diabetes melitus.

\section{Metode}

\subsection{Tempat dan Waktu Penelitian}

Penelitian ini dilaksanakan di Laboratorium Kimia Organik dan Laboratorium Biokimia FMIPA Universitas Sam Ratulangi (Unsrat), serta Laboratorium Advance Unsrat Manado selama 3 bulan yaitu bulan Mei-Agustus 2013.

\subsection{Alat dan Bahan}

Alat-alat yang digunakan yaitu sudip, batang pengaduk, labu Erlemeyer, gelas piala, labu takar, gelas ukur, pipet tetes, cawan petri, corong, tabung reaksi, kertas saring, desikator, timbangan analitik, oven, rotary evaporator, ayakan 65 mesh, nasogastric tube (NGT) no. 3,5, disposible syringe 3 $\mathrm{mL}$, pipet volumetrik dan satu set alat ukur kadar glukosa darah (KGD) merk: Nesco multi check.

Penelitian ini menggunakan tumbuhan suruhan dan hewan uji tikus jantan strain Wistar (Rattus norvegicus L.) yang sehat berumur sekitar 4-5 bulan. Bahan-bahan kimia yang digunakan yaitu etanol 95\%, heksana teknis, Carboxy Methyl Cellulose (CMC), aquades, obat penurun kadar glukosa darah bermerek Glibenklamid (Kimia Farma), pakan ternak dan sukrosa.

\subsection{Rancangan Penelitian}

Penelitian diawali dengan penyiapan ekstrak etanol dan heksana dari serbuk tumbuhan suruhan untuk diujikan pada tikus. Penelitian yang dilakukan merupakan percobaan laboratorium dengan menggunakan uji toleransi glukosa. Mula-mula 16 ekor tikus Wistar diadaptasikan dengan kondisi kandang dan pakan standar selama 1 minggu, lalu diukur kadar glukosa darah normalnya (basal). Satu tikus dipelihara dalam satu kandang. Selanjutnya, tikus dibagi ke dalam 4 kelompok perlakuan (masing-masing 4 ekor). Semua kelompok perlakuan diberi sukrosa untuk meningkatkan kadar glukosa darahnya, dan setelah 30 menit pemberian 
sukrosa, kadar glukosa darahnya diukur. Kemudian tikus pada setiap kelompok perlakuan masingmasing diberi:

1. Kelompok kontrol negatif (K-): CMC 0,5\%,

2. Kelompok kontrol positif $(\mathrm{K}+)$ : Glibenkamid (obat paten) dosis $0,45 \mathrm{mg} / \mathrm{kgBB}$,

3. Kelompok perlakuan ektrak etanol tumbuhan suruhan (EETS): ekstrak etanol tumbuhan suruhan dosis $40 \mathrm{mg} / \mathrm{kgBB}$,

4. Kelompok perlakuan ekstrak heksana tumbuhan suruhan (EETS): ekstrak etanol tumbuhan suruhan dosis $40 \mathrm{mg} / \mathrm{kgBB}$.

Kadar glukosa darah tikus diukur pada menit ke-30, 60 dan 120 setelah pemberian perlakuan

\subsection{Prosedur Percobaan}

\subsubsection{Preparasi Sampel}

Sampel tumbuhan suruhan diambil dari berbagai tempat di sekitar daerah kampus Unsrat Manado. Tumbuhan suruhan segar yang telah dikumpulkan, disortir, dicuci bersih di bawah air mengalir, ditiriskan dan ditimbang berat basahnya. Seluruh bagian tumbuhan suruhan kemudian dikeringkan dalam oven bersuhu $50^{\circ} \mathrm{C}$ hingga kadar air kurang dari 10\%. Setelah kering, tumbuhan suruhan ditimbang sebanyak 200 g, diblender hingga halus, lalu diayak dengan ayakan 65 mesh. Serbuk suruhan hasil ayakan disimpan dalam wadah plastik yang tertutup rapat, untuk dipakai pada perlakuan selanjutnya.

\subsubsection{Penentuan Kadar Air}

Penentuan kadar air menggunakan metode pemanasan dengan oven (Helrich, K., 1999). Mulamula, cawan porselin dikeringkan dalam oven bersuhu $105{ }^{\circ} \mathrm{C}$ selama 30 menit, lalu cawan didinginkan dalam deksikator selama 30 menit dan ditimbang bobot kosongnya. Sampel ditimbang sebanyak \pm 3 gram di dalam cawan porselin, dimasukkan dalam oven bersuhu $105{ }^{\circ} \mathrm{C}$ selama 3 jam kemudian didinginkan dalam desikator selama 30 menit, lalu sampel ditimbang. Kemudian dipanaskan kembali dalam oven dan didinginkan lagi sampai mencapai berat konstan. Perhitungan kadar air:

$$
\% \text { Kadar air }=\frac{\text { berat awal -berat akhir }}{\text { berat awal }} \times 100 \% \text {. }
$$

\subsubsection{Pembuatan Ekstrak Tumbuhan Suruhan}

Pembuatan ekstraksi tumbuhan suruhan dilakukan dengan cara maserasi, menggunakan pelarut etanol 95\% dan heksana teknis.

Serbuk tumbuhan suruhan sebanyak $100 \mathrm{~g}$ dicampur dengan $1 \mathrm{~L}$ etanol 95\% dan dimaserasi selama 5 hari pada suhu ruang. Campuran kemudian disaring dengan kertas saring dan diperoleh filtrat (1). Residunya dimaserasi kembali selama 2 hari menggunakan $1 \mathrm{~L}$ etanol 95\% lalu disaring, dan diperoleh filtrat (2). Selanjutnya filtrat (1) dan (2) dikumpulkan, diuapkan dengan rotary evaporator pada suhu $70{ }^{\circ} \mathrm{C}$ sampai volumenya menjadi $1 / 4$ dari volume awal dan dikeringkan dalam oven bersuhu $40{ }^{\circ} \mathrm{C}$ sampai menjadi ekstrak kental. Hal yang sama dilakukan juga terhadap $100 \mathrm{~g}$ serbuk tumbuhan suruhan yang diektraksi dengan heksana.

\subsubsection{Pembuatan Larutan}

Larutan yang dibuat terdiri atas : larutan sukrosa, pembuatan larutan Carboxy Methyl Cellulose (CMC) $0,5 \% \mathrm{~b} / \mathrm{v}$, pembuatan Iarutan Glibenklamid dosis $0,45 \mathrm{mg} / \mathrm{kgBB}$, dan pembuatan larutan ekstrak etanol dan heksana tumbuhan suruhan dosis $40 \mathrm{mg} / \mathrm{kgBB}$.

\subsubsection{Pembuatan Larutan Sukrosa}

Dosis sukrosa yang digunakan untuk tikus adalah 5625 mg/kgBB (Kanon, 2012). Dosis sukrosa yang akan digunakan, dihitung berdasarkan berat badan dari masing-masing tikus, kemudian dilarutkan dalam aquades sebanyak 2,5 $\mathrm{mL}$ dan diberikan pada masing-masing tikus.

\subsubsection{Pembuatan Larutan Carboxy Methyl Cellulose (CMC) $0,5 \%$}

Sebanyak 0,5 g CMC ditaburkan dalam gelas piala yang berisi $\pm 30 \mathrm{~mL}$ akuades yang telah dipanaskan. Didiamkan selama 15 menit hingga diperoleh massa yang transparan, lalu dicampur sampai homogen, diencerkan dengan akuades dan dimasukkan ke labu ukur 100 mL, dicukupkan volumenya dengan akuades hingga batas tanda tera.

\subsubsection{Pembuatan Larutan Glibenklamid Dosis $0,45 \mathrm{mg} / \mathrm{kg} \mathrm{BB}$}

Dosis Glibenklamid pada manusia dewasa adalah $5 \mathrm{mg}$, maka dosis Glibenklamid untuk tikus adalah 0,45 mg/KgBB sesuai Tabel Konversi Dosis Hewan dengan Manusia (Laurence and Bacharach (1964) dalam Harmita dan Radji, 2006). Tablet Glibenklamid dihaluskan dan dilarutkan dalam $1 \mathrm{~mL}$ larutan CMC 0,5\% sedikit demi sedikit sambil digerus sampai homogen. Banyaknya serbuk Glibenklamid yang dibutuhkan, dihitung berdasarkan berat badan dari masing-masing tikus.

\subsubsection{Pembuatan Larutan Ekstrak Etanol dan Heksana Tumbuhan Suruhan Dosis 40 $\mathrm{mg} / \mathrm{kg} \mathrm{BB}$}

Konsumsi tumbuhan suruhan segar pada manusia dewasa (50 kg) adalah $100 \mathrm{~g}$. Faktor konversi dosis dari manusia (70 kg) ke tikus (200 g) adalah 0,018, maka dosis yang akan diberikan kepada tikus adalah 12,6 g/kgBB untuk berat basah tumbuhan suruhan. Penelitian ini menggunakan ekstrak etanol dan heksana tumbuhan suruhan yang telah dikeringkan. Bila dikonversi ke berat basah, maka dosis untuk setiap ektrak yang diberikan ke tikus sebesar 40 mg/kgBB. Masing-masing ektrak etanol dan heksana tumbuhan suruhan dimasukkan ke dalam cawan petri dan ditambahkan $1 \mathrm{~mL}$ larutan CMC 0,5\% sedikit demi sedikit sampai homogen. Banyaknya masing-masing ektrak etanol dan heksana 
tumbuhan suruhan yang dibutuhkan, dihitung berdasarkan berat badan dari masing-masing tikus.

\subsubsection{Pengujian Efek Penurunan Kadar Glukosa Darah}

\subsubsection{Penggunaan Blood Glucose Test Meter "GlucoDr"}

Alat test GlucoDr dan strip GlucoDr merupakan alat yang digunakan untuk pengujian sendiri dari luar tubuh (invitro) yang digunakan dalam pengukuran kadar glukosa dalam kapiler segar. Glucometer ini secara otomatis akan hidup ketika glucose test strip dimasukkan dan akan mati setelah glucose test strip dicabut. GlucoDr Strip dimasukkan ke alat GlucoDr sehingga glucometer ini akan hidup secara otomatis, kemudian dicocokkan kode nomor yang muncul pada layar dengan yang ada pada vial GlucoDr Check glucose test strip. Test strip yang dimasukkan pada glucometer pada bagian layar akan tertera angka yang harus sesuai dengan kode vial GlucoDr Check glucose test strip, kemudian pada layar monitor glukometer muncul tanda siap untuk diteteskan darah. Caranya dengan menyentuh 1 tetes darah yang keluar ke test strip dan ditarik sendirinya melalui aksi kapiler. Ketika wadah terisi penuh oleh darah, alat mulai mengukur kadar glukosa darah. Hasil pengukuran diperoleh selama 10 detik.

\subsubsection{Pegukuran Kadar Glukosa Darah}

Sebelum percobaan dilakukan, tikus dipuasakan (tidak diberi makan tetapi tetap diberi minum) selama 12 jam, lalu ditimbang berat badan tikus. Masing-masing tikus diukur kadar glukosa darah normal (basal) dengan cara mengambil darah melalui pembuluh darah vena dibagian ekor yang telah digunting. Darah yang keluar disentuhkan pada test strip yang terpasang pada alat glukometer dan dibiarkan alat mengukur kadar glukosa darah secara otomatis. Angka yang tampil pada layar dicatat sebagai kadar glukosa darah $(\mathrm{mg} / \mathrm{dL})$.

2.4.5.3. Pengujian Efek Ekstrak Etanol dan Heksana Tumbuhan Suruhan Terhadap Kadar glukosa darah Tikus yang Diinduksi Sukrosa

Semua tikus yang telah dipuasakan ditimbang berat badannya, kemudian diperiksa kadar glukosa darah puasa, setelah itu semua tikus diinduksi sukrosa sebesar 5,625 g/kgBB. Setelah 30 menit, semua tikus diperiksa kadar glukosa darah sesudah diinduksi sukrosa. Selanjutnya, semua tikus diberi sediaan per oral, untuk kelompok perlakuan kontrol negatif diberi $\mathrm{CMC}$ 0,5\%, kelompok perlakuan kontrol positif diberi Glibenklamid dosis 0,45 $\mathrm{mg} / \mathrm{kgBB}$, dan kelompok perlakuan masing-masing diberi dosis $40 \mathrm{mg} / \mathrm{kgBB}$ pada ektrak etanol tumbuhan suruhan (EETS) dan ekstrak heksana tumbuhan suruhan (EHTS) kemudian kadar glukosa darah tikus diperiksa pada menit ke-30, 60, dan 120 setelah diberi perlakuan. Semua sampel darah diambil dari vena ekor tikus dan kadar glukosa darah diukur dengan glukometer GlucoDr dan GlucoDr Strip (Blood Glucose Test Meter).

\subsubsection{Analisis Data}

Data yang diperoleh dianalisis dengan menggunakan program statistika SAS. Beda nyata antar perlakuan diuji dengan ANAVA yang kemudian dilanjutkan dengan uji Duncan.

\section{Hasil dan Pembahasan}

\subsection{Ekstraksi Tumbuhan Suruhan}

Pengujian ekstrak etanol dan ekstrak heksana tumbuhan suruhan dilakukan untuk menguji kemampuan senyawa polar dan nonpolar dari ekstrak tersebut dalam menurunkan kadar glukosa darah. Metode ekstraksi yang digunakan adalah maserasi karena pekerjaannya cukup sederhana selain itu zat aktif tidak rusak oleh pemanasan tinggi karena dilakukan pada suhu kamar. Hasil ekstraksi tumbuhan suruhan $100 \mathrm{~g}$ dalam 1L pelarut etanol 95\% dan heksana dapat dilihat pada Tabel 1.

Tabel 1. Hasil ekstraksi maserasi tumbuhan suruhan.

\begin{tabular}{|c|c|c|}
\hline Ekstrak Pelarut & $\begin{array}{c}\text { Ekstrak Kental } \\
(\mathrm{g})\end{array}$ & $\begin{array}{c}\text { Rendemen } \\
(\%)\end{array}$ \\
\hline EETS & 6,871 & 6,87 \\
\hline EHTS & 2,59 & 2,59 \\
\hline
\end{tabular}

Catatan: EETS (Ekstrak etanol tumbuhan suruhan) dan EHTS (Ekstrak heksana tumbuhan suruhan)

Pada Tabel 1, ekstrak dengan pelarut etanol memiliki rendemen yang lebih besar dibandingkan pelarut heksana. Hal ini membuktikan bahwa sebagian besar senyawa yang terdapat pada tumbuhan suruhan merupakan senyawa polar.

\subsection{Pengaruh Ekstrak Tumbuhan Suruhan terhadap Kadar Glukosa Darah}

Pada penelitian ini dilakukan pengamatan potensi penurunan kadar glukosa darah pada hewan uji tikus putih jantan Wistar dengan berat badan 83g - 165g. Pengukuran kadar glukosa darah pada penelitian ini menggunakan alat glukometer Gluco-Dr. Pada alat Gluco-Dr terdapat enzim GOD-PAP yang berperan dalam reaksi pengukuran kadar glukosa darah.

Metode uji yang digunakan yaitu uji toleransi glukosa oral (UTGO) terhadap tikus putih jantan galur wistar. Menurut Barorah et al., (2011), tikus jantan dipilih karena kondisi hormonal tikus jantan relatif stabil sehingga tidak banyak mempengaruhi metabolisme dalam tubuhnya. Tikus yang digunakan adalah tikus normal yang dibebani sukrosa tanpa merusak pankreasnya, karena berdasarkan teori bahwa dengan pembebanan sukrosa akan menyebabkan peningkatan kadar glukosa darah (hiperglikemik) secara cepat. Sukrosa di dalam tubuh dapat terurai menjadi glukosa dan fruktosa. Kadar glukosa yang tinggi dalam darah dapat diturunkan oleh zat-zat berefek antihiperglikemik. 
Pengukuran kadar glukosa darah dilakukan sebanyak lima kali yaitu kadar glukosa darah sebelum dan sesudah diinduksikan sukrosa serta, kadar glukosa darah menit ke-30, 60, dan 120 setelah diinduksi ekstrak etanol dan heksana dari tumbuhan suruhan. Hasil pengukuran kadar glukosa darah $(\mathrm{mg} / \mathrm{dL})$ tikus dengan metode uji toleransi glukosa untuk setiap kelompok dapat dilihat pada Tabel 2. Prosentase penurunan kadar glukosa darah dari setiap kelompok tikus yang hiperglikemia disajikan pada Gambar 1.

Tabel 2. Hasil Pengukuran Rata-Rata Kadar Glukosa Darah pada Tikus

\begin{tabular}{|c|c|c|c|c|c|}
\hline \multirow{2}{*}{ Kelompok Perlakuan } & \multicolumn{5}{|c|}{ Rata-Rata Kadar Glukosa Darah $(\mathrm{mg} / \mathrm{dL})$} \\
\cline { 2 - 6 } & \multirow{2}{*}{ Basal } & \multirow{2}{*}{ Induksi sukrosa } & \multicolumn{3}{|c|}{ Waktu Setelah Induksi sukrosa } \\
\cline { 4 - 6 } & & & 30 menit & 60 menit & 120 menit \\
\hline K(-) & $82.67^{\mathrm{k}}$ & $232.00^{\mathrm{c}}$ & $242.67^{\mathrm{b}}$ & $252.00^{\mathrm{a}}$ & $209.67^{\mathrm{d}}$ \\
\hline $\mathrm{K}(+)$ & $73.67^{1, \mathrm{~m}}$ & $180.67^{\mathrm{e}}$ & $132.33^{\mathrm{h}}$ & $108.67^{\mathrm{j}}$ & $77.33^{\mathrm{k}, \mathrm{l}, \mathrm{m}}$ \\
\hline EETS & $72.5^{1, \mathrm{~m}}$ & $175^{\mathrm{e}}$ & $145.25^{\mathrm{g}}$ & $122.5^{\mathrm{i}}$ & $79.5^{\mathrm{k}, \mathrm{l}}$ \\
\hline EHTS & $70.33^{\mathrm{m}}$ & $173.67^{\mathrm{e}}$ & $159^{\mathrm{f}}$ & $131^{\mathrm{h}}$ & $84.67^{\mathrm{k}}$ \\
\hline
\end{tabular}

Catatan: huruf yang sama dibelakang angka menunjukkan tidak berbeda nyata.

Keterangan : $\quad \mathrm{K}(-)$ : Kelompok Perlakuan Kontrol Negatif diberi CMC 0,5\%

$\mathrm{K}(+)$ : Kelompok Perlakuan Kontrol Positif diberi Glibenklamid dosis 0,45 mg/kgBB

EETS : Kelompok Perlakuan Ekstrak Etanol Tumbuhan Suruhan dosis $40 \mathrm{mg} / \mathrm{kgBB}$

EHTS : Kelompok Perlakuan Ekstrak Heksana Tumbuhan Suruhan dosis 40 mg/kgBB

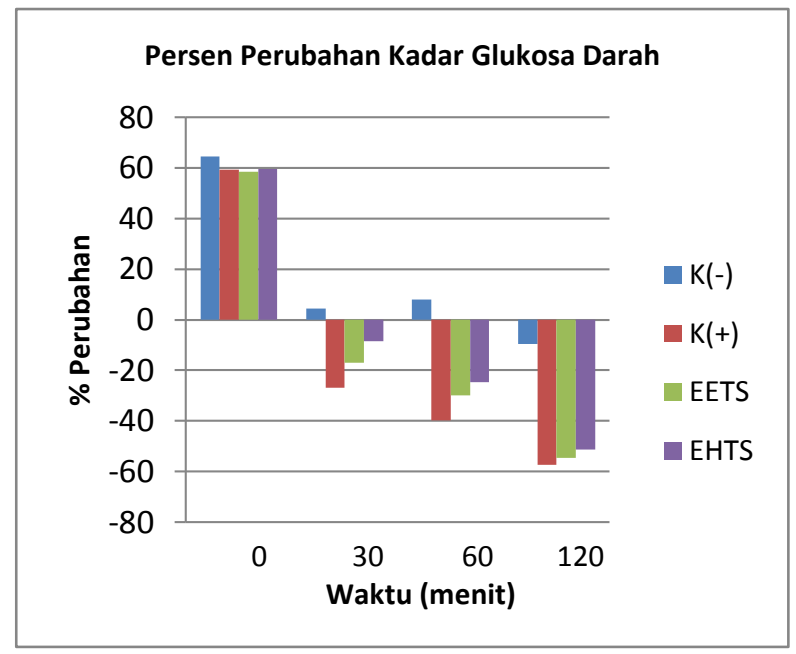

\section{Gambar 1. Prosentase Perubahan Kadar Glukosa Darah}

Berdasarkan Table 2, kadar glukosa darah normal dari tikus untuk semua perlakuan berkisar antara 70,33-82,67 mg/dL. Hasil penelitian ini mendukung hasil peneltian Wulandari (2010) yang melaporkan bahwa kadar glukosa darah normal dari tikus Wistar yaitu $<110 \mathrm{mg} / \mathrm{dL}$.

Untuk membuat kondisi hiperglikemia, tikus diinduksi dengan sukrosa dosis 5625 mg/KgBB. Setelah 30 menit diinduksi sukrosa, kadar glukosa darah semua kelompok perlakuan mengalami kenaikan 58.57-64.37\%. Kadar glukosa darah pada kelompok K(-) sebesar $232 \mathrm{mg} / \mathrm{dL}$ atau naik $64.37 \%$, kelompok $\mathrm{K}(+)$ sebesar $180.67 \mathrm{mg} / \mathrm{dL}$ atau naik 59.22\%, kelompok EETS sebesar $175 \mathrm{mg} / \mathrm{dL}$ atau naik $58.57 \%$, dan kelompok EHTS sebesar $173.67 \mathrm{mg} / \mathrm{dL}$ atau naik 59.50\%. Kanon (2012) melaporkan bahwa tikus yang diinduksi dengan larutan sukrosa $5625 \mathrm{mg} / \mathrm{kgBB}$ dapat menyebabkan hiperglikemia dengan kenaikan kadar glukosa darah $>50 \%$. Pada tahap ini, semua tikus telah menderita hiperglikemia. Kondisi hiperglikemia ini disebabkan oleh pemberian sukrosa dengan dosis yang relatif tinggi. Sukrosa dalam sel epitel usus halus akan dihidrolisis oleh enzim sucrase menghasilkan glukosa dan fruktosa (Nelson dan Cox, 2005). Pada usus halus terjadinya penyerapan glukosa dan masuk ke peredaran darah, sehingga meningkatkan kadar glukosa darah.

Pemberian ekstrak etanol (EETS) dan heksana (EHTS) dari tumbuhan suruhan dapat menurunkan kadar glukosa darah tikus yang hiperglikemia (Tabel 2). Pada pemberian ekstrak etanol dan heksana tumbuhan suruhan, masing-masing dengan dosis $40 \mathrm{mg} / \mathrm{KgBB}$ terjadi penurunan kadar glukosa darah (KGD) dari menit ke-30 sampai menit ke-120 setelah pemberian ekstrak, dan memberikan perbedaan yang nyata dengan kontrol negatif $(\mathrm{K}(-))$ yang diberi suspensi CMC 0,5\% b/v. Pada kelompok $\mathrm{K}(-)$ penurunan kadar glukosa darah sebesar $4.40 \%$ (menit ke-30), 7.94\% (menit ke-60) dan 9.63\% (menit ke-120). Tidak ada perbedaan nyata kadar glukosa darah tikus antara kelompok $\mathrm{K}(+)$, EETS dan HETS.

Pada menit ke-120 setelah pemberian ekstrak, kadar glukosa darah tikus turun sebesar 54,57\% pada kelompok EETS dan 51,25\% pada EHTS (Gambar 1). Kadar glukosa darah tikus pada kelompok EETS dan EHTS tidak berbeda nyata dengan kelompok $\mathrm{K}(+)$ yang diberi obat Glibenklamid $(P<0,05)$. Pada menit ke-120 tersebut, kadar glukosa darah tikus pada kelompok $\mathrm{K}(+)$ dan EETS tidak berbeda dengan kadar glukosa normalnya (basal). Hasil ini sejalan dengan hasil penelitian yang dilaporkan oleh Kusumawarni et al., 2012 bahwa fraksi etil asetat dari tumbuhan suruhan memiliki aktivitas antidiabetes dengan persentase penurunan $53.44 \%$.

Sebagai kontrol positif digunakan Glibenklamid. Glibenklamid adalah obat paten yang 
digunakan oleh penderita diabetes, dan berfungsi meningkatkan sekresi insulin. Glibenklamid hanya efektif pada diabetes mellitus tipe 2 yang keadaan diabetesnya tidak begitu berat dan yang sel betanya masih bekerja cukup baik (Tjay dan Rahardja, 2007, dalam pasaribu 2012).

Meskipun telah diketahui pelarut etanol digunakan untuk menghasilkan sediaan obat, tetapi beberapa hasil penelitian menunjukan bahwa pelarut seperti heksana sering juga dimanfaatkan untuk mengekstrak bahan-bahan yang berkhasiat sebagai antihiperglikemik. Seperti penelitian yang dilaporkan oleh Yulinah et al. (2001) bahwa ektrak heksana daun sambiloto dapat menurunkan kadar glukosa darah mencit yang diinduksi dengan aloksan secara bermakna.

Mekanisme penyembuhan penyakit diabetes oleh ektrak tumbuhan tertentu berkaitan erat dengan kandungan flavonoid dalam tumbuhan tersebut. Flavonoid diduga berperan dalam meingkatkan aktivitas enzim antioksidan dan mampu meregenerasi sel-sel $\beta$-pankreas yang rusak sehingga defisiensi insulin dapat diatasi. Flavonoid diduga juga dapat memperbaiki sensitifitas reseptor insulin, sehingga memberikan efek yang menguntungkan bagi penderta diabetes mellitus (Marianne, 2011).

Tumbuhan suruhan mengandung flavonoid Ukieyanna (2012). Senyawa flavonoid bersifat polar sehingga dapat larut dalam senyawa polar, seperti etanol, dan sedikit larut dalam pelarut non-polar, seperti heksana. Kemampuan ekstrak tumbuhan suruhan dalam menurunkan kadar glukosa darah tikus yang hiperglikemia pada penelitian ini, diduga disebabkan oleh senyawa flavonoid yang terkandung dalam tumbuhan suruhan. Kemampuan menurunkan kadar glukosa darah dari ekstrak etanol tumbuhan suruhan lebih besar daripada ekstrak heksananya. Penelitian Suarsana (2009) menyebutkan bahwa senyawa flavonoid dapat menurunkan kadar glukosa darah tikus dengan cara merangsang sel $\beta$-pankreas untuk memproduksi insulin lebih banyak.

\section{Penutup}

\subsection{Kesimpulan}

Penelitian ini menyimpulkan bahwa ektrak etanol dan heksana tumbuhan suruhan (Peperomia pellucida [L.] Kunth) dosis $40 \mathrm{mg} / \mathrm{KgBB}$ memiliki efek hipoglikemik (menurunan glukosa darah) tikus putih jantan wistar yang hiperglikemik. Efek Hipoglikemik ektrak etanol tumbuhan suruhan lebih besar daripada ekstrak heksana.

\subsection{Saran}

Perlu dilakukan penelitian lebih lanjut mengenai pengujian toksisitas pada tumbuhan suruhan.

\section{Daftar Pustaka}

Barorah, F., N.Aznam, dan H.Susanti. 2011. Uji Efek Antihiperglikemik Ekstrak Etanol Daun Kacapiring (Gardenia augusta, Merr) pada Tikus Putih Jantan Galur Wistar. Jurnal IImiah Kefarmasian. 1: 43-53.

Dalimartha, S. 2006. Atlas Tumbuhan Obat Indonesia Jilid 4. Puspaswara: Jakarta.

Helrich, K. 1999. Official Methods of Analysis of Association of Official Analitical Chemists. Edisi ke15.Chapter 44.1.03, Association of Official Analytical Chemist [AOAC]. United States of America.

Harmita., dan M. Radji. 2006. Buku Ajar Analisis Hayati. Edisi Ke-3. Buku Kedokteran EGC, Jakarta.

Kanon, M.Q., Fatimawali dan Bodhi, W. 2012. Uji Efektivitas Ekstrak Kulit Buah Salak (Salacca zalacca (Gaertn.) Voss) terhadap Penurunan Kadar glukosa darah Tikus Putih Jantan Galur Wistar (Rattus norvegicus L.) yang Diinduksi Sukrosa. Pharmacon. 2: 52-58.

Kawatu, C., W. Bodhi dan J. Mongi. 2013. Uji Efek Ekstrak Etanol Daun Kucing-Kucingan (Acalypha Indica L.) terhadap Kadar glukosa darah Tikus Putih Jantan Galur Wistar (Rattus novergicus). PHARMACON Jurnal IImiah Farmasi. 2: 81-85.

Kusumawarni , P., Supriyatna, dan Y. Susilawati. 2012. Aktivitas Antidiabetes Fraksi Etil Asetat dari Herba Sasaladaan (Peperomia pellucida (L.) Kunth.) dengan Metode Induksi Aloksan. eJournal Mahasiswa Universitas Padjadjaran. Vol. (1).

Marianne, Yuandani, dan Rosnani. 2011. Antidiabetic Activity from Ethanol Extract of Kluwih's Leaf (Artocarpus camansi). Jurnal Natural. 11: 64-68.

Nelson, D. L.dan M.M. Cox. 2005. Lehninger Principles of Biochemistry Ed Ke-4. W H. Freeman.

Pasaribu, F. P. Sitorus dan S. Bahri. 2012. Uji Ekstrak Etanol Kulit Buah Manggis (Garcinia mangostana L.) Terhadap Penurunan Kadar Glukosa Darah. Journal of Pharmaceutics and Pharmacology. 1: 1-8.

Suarsana, I. N. 2009. Aktivitas Hipoglikemik dan Anti Oksidatif Ekstrak Metanol Tempe pada Tikus Diabetes [Tesis]. Sekolah Pascasarjana Institut Pertanian Bogor, Bogor.

Ukieyanna, E. 2012. Aktivitas Antioksidan, Kadar Fenolik, dan Flavonoid Total Tumbuhan Suruhan (Peperomia pellucida L. Kunth) [skripsi]. FMIPA IPB: Bogor.

Wulandari, C. E. 2010. Pengaruh Pemberian Ekstrak Bawang Merah (Allium Ascalonicum) Terhadap Penurunan Kadar Glukosa Darah Pada Tikus Wistar Dengan Hiperglikemia [Karya Tulis IImiah]. Universitas Dipenogoro: Semarang.

Yulinah, E., Sukrasno, M.A.Fitri. 2001. Aktivitas Antidiabetika Ekstrak Etanol Herba Sambilota (Andrographis paniculata Nees (Acanthaceae)). Bandung:Jurusan Farmasi Fakultas MIPA Institut Teknologi Bandung. 